\title{
Gender and Bankruptcy: A Hotel Survival Econometric Analysis
}

\author{
María Escribano-Navas ${ }^{1}(\mathbb{D})$ and German Gemar ${ }^{2, *(D)}$ \\ 1 PhD Program in Tourism, Universidad de Málaga, 29071 Málaga, Spain; mescribano@uma.es \\ 2 Department of Economics and Business Administration, Universidad de Málaga, Campus El Ejido, s/n, \\ 29071 Malaga, Spain \\ * Correspondence: ggemar@uma.es
}

check for updates

Citation: Escribano-Navas, M.;

Gemar, G. Gender and Bankruptcy: A Hotel Survival Econometric Analysis. Sustainability 2021, 13, 6782. https:// doi.org/10.3390/su13126782

Academic Editors: Asad Mohsin, Ana Brochado and Andi Tamsang Andi Kele

Received: 20 April 2021

Accepted: 4 June 2021

Published: 15 June 2021

Publisher's Note: MDPI stays neutral with regard to jurisdictional claims in published maps and institutional affiliations.

Copyright: (c) 2021 by the authors. Licensee MDPI, Basel, Switzerland. This article is an open access article distributed under the terms and conditions of the Creative Commons Attribution (CC BY) license (https:/ / creativecommons.org/licenses/by/ $4.0 /)$.

\begin{abstract}
This study's objective was to understand how chief executive officers' (CEOs) gender affects hotel businesses' survival. Female managers' influence has already been examined in other sectors, but researchers have not studied women CEOs' role in hotel management and survival. A sample of 2615 Spanish hotel companies was examined during the period 2005-2018 for how their survival was affected by the variables of financial aspects, years of experience and the principal hotel executive's gender. An econometrics-based survival analysis was conducted using a single complementary log-log model and panel data. The results indicate that some financial variables, such as sales, working capital to total assets ratio and each company's experience, influence hotel businesses' survival. The main finding was that women CEOs increase hotels' survival rate. This CEO gender study is a novelty in the literature on hotel survival.
\end{abstract}

Keywords: survival; hotel company; gender; executive management; COVID-19

\section{Introduction}

Research on company survival has a long tradition, but hotel survival studies are scarcer. Spain has the second highest number of arrivals annually, after France, and Spain is only behind the United States in terms of tourism income [1]. The present research sought to fill this research gap to expand the existing knowledge on hotel survival. The question addressed was whether differences exist in the survival of female-led hotel businesses versus those headed by males. More studies are needed to deepen the current understanding of hotel companies' survival because managers need help to overcome the current crisis in tourism triggered by COVID-19.

Before this coronavirus appeared, various authors summed up the hospitality industry's opportunities and challenges. Among the opportunities reported were new forms of financing through management contracts using real estate investment trusts and the emergence of new markets. The challenges mentioned were a better understanding of customers through big data analyses and co-creation of tourists' experiences. The overall results indicated that hotels should use technology including smart hotels, mobile applications and virtual environments, among others [2].

Hall [3] reports that globalisation and tourists' reliance on mobile phones has increased the probability that world crises will affect international tourism in terms of impacts' intensity and frequency. The cited author and other researchers have warned that the current model of tourism is fragile because, in many cases, liquidity and profitability are marginal. In addition, transport systems have excess capacity, and important phenomena such as Airbnb are not yet fully regulated $[4,5]$.

The COVID-19 pandemic is changing societies, economies and tourism. Academic researchers need to analyse these changes to facilitate a shift towards a more sustainable tourism model [4], which requires recovery strategies to be activated. Prior studies have examined plans for disaster and crisis recovery in the tourism sector, finding negative factors that slow recuperation and positive aspects that favour it [6]. The latter cited authors 
suggest that tour operators need to prepare strategies for coping with crises and disasters. The first step is to understand the phenomenon of survival. For example, much is known about how the Spanish hotel industry behaves in crises [7], but the current coronavirus crisis may require changes in business models to increase sustainability [8].

This challenge encourages critical analyses of tourism growth models to understand the risks related to new viruses and mitigate or eliminate the current models' effects on the environment [4]. The study of hotel company survival comes to the fore because it ensures this new growth model can be reformulated in a sustainable context. Despite the importance of predicting survival and bankruptcy, few studies have reviewed the literature on the subject, and most have focused on comparative evaluations of the available models' predictive power. Large samples are also needed to obtain more reliable, robust results $[9,10]$.

Concurrently, women managers' role in financial performance has been studied, but the results are inconclusive since various researchers have found gender diversity to be a positive factor and others have reported the opposite findings. Among the former group are Campbell and Mínguez-Vera [11] and the latter includes Joecks, Pull and Vetter [12]. The literature on women hotel managers is even more restricted [13]. The current study's originality consists of combining all these aspects: Female executive directors' contributions to hotel companies' survival.

The phenomenon of business survival has already been extensively studied, [14], and a multitude of financial ratios and external variables are known to influence the chances that companies will survive. Progress has also been made in terms of techniques and models with improved predictive power, although many aspects still need to be explored. Companies' economic and financial performance have been examined extensively. The most studied internal variables affecting survival are company size, financial structure, performance and current liquidity measures [15]. Other aspects related to human capital have also been studied [16], as well as external factors such as crisis contexts [17], factors related to companies' market [18] and networks or associations and their influence [19]. Finally, some research has combined several fields.

Despite all these contributions, hotel survival still remains under-researched, and no article has yet been published regarding the influence of chief executive officers' (CEOs) gender on this phenomenon. Women in hotel businesses have been investigated, such as clients or workers, but not their role as executive directors. The present study focused on determining female CEOs' effect on hotel business survival in Spain, as this country's tourism revenues are the second highest worldwide-only surpassed by the United States.

The economic aspects of hotel survival knowledge are essential given the economic crisis triggered by the COVID-19 pandemic and its especially strong impact on the tourism sector. Regarding social aspects, women managers' contributions must be understood in terms of achieving long-term sustainability and creating wealth. These women's significance also needs to be clarified at a time when many women with high levels of training and specialisation are entering the labour market. On a scientific level, all the above aspects help fill research gaps and lay the foundation for further studies by examining in detail the issue of female executive directors and their role in corporate governance and sustainability in tourism.

According to Kliestik et al. [14], academic research on company survival began in the 1930s with Fitzpatrick's [20] first study. An interest in evaluating companies' creditworthiness prompted various authors' work, including Beaver's [21] research. Analyses were based on comparing ratios, which served as the basis for a survival model's design [22]. The latter author's model seeks to detect a linear combination of characteristics that best discriminates between failed and surviving companies, so credit institutions have used this model. Other models have subsequently emerged in which logistic or logit regression is applied. They identify ratios or measures to predict bankruptcy, such as company size, financial structure measures, performance standards and current liquidity measures [15]. 
More recently, big data techniques have been introduced to obtain financial information [23]. Other alternatives are data envelopment analysis [24], data mining, decision trees [25] and support vector machines [26]. Statistical tools have thus been frequently used to predict companies' bankruptcy, including multiple discriminant analysis, logistic regression and survival analysis. Artificial intelligence tools are also important, such as artificial neural networks, support vector machines, approximate sets, reasoning based on cases, decision trees and genetic algorithms. The present research used a statistical tool, namely, survival analysis based on complementary log-log and logistic regression models.

To explain why companies go bankrupt, researchers have focused on different aspects such as economic performance, human factors and their influence on company results. Firms have also been studied as a component of business ecosystems, networks and associations, including how motivations and conditions define companies' market exit. These aspects are summarised in greater detail in the following subsections.

Companies can exit by liquidating assets or being sold to other corporations. Failure can occur in not only firms with financial problems, but also profitable companies [27]. However, the present study focused on investigating the factors that contribute to market exits due to financial problems and poor economic performance.

Growth, profitability and survival have been studied from an evolutionary theory perspective [28]. The cited authors developed a model that explains how start-ups reduce uncertainty about their ability to thrive in a market by monitoring profitability changes. Delmar, McKelvie and Wennberg [28] confirmed the idea that profitability favours growth, which increases profitability but can sometimes negatively affect survival rates. This relationship can be explained by how some companies do not survive when they grow because they are bought by other companies and thus change their corporate name. According to various authors, company size reflects the volume of investment in assets that can delay companies' market exit [29].

Human capital theory examines founders' characteristics and human factors, the general human capital available through training and specific human capital (i.e., practice and experience in relevant sectors). Based on this theory, various authors have found that general capital influences company growth and this growth influences businesses' survival. In contrast, specific human capital has a direct effect on newly founded companies [30].

In the technological sectors in which human capital has the greatest influence, high and low technology sectors have been compared. Entrepreneurial human capital-measured as educational training - reduces the probability of bankruptcy in high-tech sectors, although this type of capital does not significantly help firms in low-tech sectors [31]. Other studies have investigated organisations' failure and discovered that information processing capacities interact with shrinking human capital to cause businesses' weakening and exit [16].

Regarding external macroeconomic factors, early studies suggested that these variables are associated with between $30 \%$ and $50 \%$ of small businesses' failures [32]. More recently, researchers have examined external factors in the 2008 crisis and Lehman Brothers' bankruptcy [17]. For example, companies in competitive industries are more likely to achieve better economic performance and less likely to suffer financial problems. In addition, dependence on customers or suppliers increases the chances of failure [18].

Companies' networks and associations can also influence their long-term evolution. For instance, formal and informal networks are positively associated with company survival [33]. The present study classified banks, business consultants, external accountants and industry associations as formal networks and local businesses and family and friends as informal networks. Prediction of bankruptcy among related companies [19] and the spread of risk between firms [34] have also been studied. The relationships established to obtain financing also appear to influence bankruptcy rates [35].

Researchers have more recently focused on joining different approaches to obtain richer results. Various studies have indicated that organisational characteristics such as number of employees, invested capital and market strategies are aspects that most strongly 
influence survival [36]. Other research has emphasised that growth and internationalisation contribute to a better chance of survival for new companies [37].

The discussion in the literature about gender diversity's effect on firms' financial performance has been extensive. According to recent bibliographical reviews [38], various authors have found a positive correlation between gender diversity and financial performance [11,39]. Other studies, however, have revealed a negative link [12]. The latter research has shown that the relationship between gender diversity and company performance follows a U-shape. Gender diversity initially negatively affects performance, but a 'critical mass' of approximately $30 \%$ of women has a positive effect on performance [12,38,40]. Finally, another set of studies have not confirmed a significant relationship between gender and companies' financial performance [41].

Research on hotel survival has focused on multiple aspects. These include the strategies adopted: Franchised hotels, hotels operated by companies and ownership structures [42]. Other scholars have investigated the recent economic crisis's impact on tourism sector companies [43].

\section{Hypotheses Formulation}

This section presents the hypotheses developed based on the literature review, which suggest variables that could affect hotel survival.

Based on the literature on duration of life described in the previous section, survival's determinants can be internal or external. The internal variables selected for this research were experience, sales volume, financial structure and management.

Experience or age influences the probability of survival, according to Vivel-Búa et al. [44]. This relationship is inverse because younger companies have less experience, balance and structure $[45,46]$. According the "liability of newness", this theory has been used by many authors as Bruderl and Schussler [47]. It is shown that mortality, depending on the initial resource endowments of a firm, peaks between one and fifteen years after founding. Based on above findings, the present research included the following hypothesis:

Hypothesis 1. Companies' experience or age has a positive influence on their survival in the hotel industry.

To determine if a tourism company is healthy, its sales must be examined. Troubled tourism businesses need to develop detailed strategies to improve their sales and profits [48]. In the present investigation, sales were measured using the natural logarithm of the sales figures' net amount. The present study, therefore, incorporated a second hypothesis:

Hypothesis 2. Companies' size has a positive influence on their survival in the hotel industry.

Cash flow as a determinant of survival in organizations is studied by some authors such as Gemar et al. [49]. The following hypothesis was thus incorporated into the present study:

Hypothesis 3. Companies' cash flows have a positive influence on their survival in the hotel industry.

In addition, economic-financial structure has a long tradition in the literature as a predictor of survival [20-23]. In the current research, various economic-financial variables were selected based on Vivel-Bua et al.'s suggestions [44]. Based on the above findings, the present research included the following two hypotheses:

Hypothesis 4. Performance rotation has an influence on hotel survival.

Hypothesis 5. Working capital/Total assets Ratio influences hotel survival.

According to authors such as Gemar et al. [49], hotel management also influences these firms' survival. This following hypothesis was thus incorporated into the present research: 
Hypothesis 6. Good management practices have an influence on hotel survival.

So, the variable of hotel executive directors' gender was included. Evidence for CEO gender's effect on performance remains scant and inconsistent. Previous studies have indicated that female gender has a negative influence on businesses' continuity [50]. However, other researchers have reported that, after considering specific aspects of the industry in question, no differences exist in failure rates between female- or male-owned firms [51].

Among the studies mentioning a positive influence, some have focused on profitability and performance [52-54], while other research has pointed to lower leverage, less volatile earnings and a higher probability of survival [55]. Various authors have suggested a direct link exists between gender and performance, but others who studied tourism companies listed on the stock exchange did not find that gender influences performance [56]. In the present research, the companies in the sample were mostly small and mediumsized enterprises, so CEO gender's influence on these firms could be different from the effect it can exert on larger companies. The present study, therefore, incorporated the following hypothesis:

Hypothesis 7. Hotel CEOs' gender influences their business's survival.

\section{Materials and Methods}

\subsection{Data}

The current research used observations of 2615 companies over 14 years from 2005 to 2018, gathering all the available information from the Iberian Balance sheet Analysis System's (SABI) database. The data were collected in March 2020. In Spain, annual accounts kept in the government's commercial register are filed in July of the following year. Thus, in March 2020, the last accounts available were for 2018. The SABI database contains information on small and medium-sized companies in Spain, which allowed this study to examine data on Spanish companies of different sizes. In addition, SABI has extensive financial information of interest to this research.

In Spain, studies of survival within the tourism and hospitality industry are still relatively scarce, with some notable exceptions [44,49]. The present study sought to address this research deficit even as the Spanish hotel industry entered into an especially critical period.

The present study's variable of interest is hotels' duration defined as the time elapsed between entering and leaving the hotel industry, that is, the period between the founding of the company (i.e., entry) until the end of its activities (i.e., exit). This variable has also been called 'duration of life'. For some hotels, this period can be fully observed based on when the establishments stop operating during the time interval under study, while other hotels may have to be subject to 'censored' observations if the exit does not occur before the interval ends [49].

The current study applied the state of 'active' to firms that had not had problems and that were healthy, living companies. The remaining firms were considered to have failed. Businesses failed for different reasons including bankruptcy and insolvency creditors, among other situations.

In the present survival analysis based on panel data, the observation window included 14 years. The data contained some companies that were observable in that window for four years or less. One observation was made per year for each company. The gender variable was assigned a value of 1 for each year that the CEO was a woman and 0 if he was a man. In Spain, CEOs remain in their position 8.96 years on average, and the subsector with the lowest turnover among CEOs is precisely that of 'leisure, tourism and hospitality' (0.8\%). Normally, shareholders grant a new CEO an initial term of four years when the CEO is elected [57]. 
The SABI database only reports information on company CEOs based on the last year these data are filed. Since the average duration of CEOs' term in Spanish companies is 8.96 years, further data were gathered for the current research via an exhaustive search of news sources using keywords. The selected companies' corporate governance reports were also consulted so that most changes in CEOs could be identified.

Companies that appeared in this study's data for less than four years were thus assumed to have kept the same CEO. In the remaining cases, CEO information was searched for intensively, and companies were omitted from the dataset if this information was unavailable.

\subsection{Methodology}

The current study sought to obtain data expressed in terms of survival, that is, to include a variable that measures the time that elapses until a given company closes. Therefore, survival was defined as a measure of the time until the event under study occurred. The term 'survival' was originally only used in biomedical research on patients' death.

In survival studies, the observation of each patient (i.e., company) begins with the diagnosis, which is considered the start date and equal to 0 . The observation continues until the event of interest occurs or until the follow-up time ends. When this time runs out before the relevant event happens, the observation is referred to as 'censored' or 'incomplete' since the event of interest has not yet occurred. Each observation's start and end dates are different as patients (i.e., companies) join the database and die (i.e., fail) at different times.

The present analysis included two significant variables: A dependent variable that indicated the time elapsed until the event of interest (i.e., company failure) and a second variable that designated whether failure had occurred. The time elapsed until the specific event (i.e., company failure) was calculated with reference to other explanatory variables (i.e., experience, sales, financial structure and CEO gender). Although quantitative, the time variable did not follow a normal distribution, and 'death' had not occurred in some observations by the end of the research period. When the follow-up phase ends before the terminal event occurs, this pattern is known as a 'censored' observation. Given these particularities in the data, the type of analysis selected was considered appropriate for the present study [58].

\subsubsection{Survival and Hazard Rate in Discrete Time}

The following mathematical explanation of the current research's functions is based on Jenkins's [59] (p. 17) work. In the present investigation, the assumption was made that the time axis can be divided into a series of contiguous, non-overlapping or disjoint intervals in which the interval limits were the dates $a_{0}=0, a_{1}, a_{2}, a_{3}, \ldots, a_{k}$. The intervals themselves were described by Equation (1):

$$
\left[0=a_{0}, a_{1}\right],\left(a_{1}, a_{2}\right],\left(a_{2}, a_{3}\right], \ldots,\left(a_{k-1}, a_{k}=\infty\right]
$$

In this study, time was considered to be discretely divided into intervals of years. The calculations for year $\mathrm{j}$ were based on the interval $\left(a_{j-1}, a_{j}\right]$. Survival analyses seek to obtain a time-dependent function whose value represents the probability that the terminal event occurs after a time $t$. In this case, the function is called the 'death risk' or hazard ratio. This study's failure function or $F(t)$ before the beginning of year $j$ was expressed as Equation (2):

$$
F(t)=\operatorname{Pr}\left(T \leq a_{j-1}\right)
$$

The probability that a death event would not occur was calculated, after which survival was estimated until the end of time $t$.

The survival function was calculated based on the death risk function or hazard ratio. The survival function's value at the beginning of year $j$ was given as Equation (3):

$$
\operatorname{Pr}\left(T>a_{j-1}\right)=1-F\left(a_{j-1}\right)=S\left(a_{j-1}\right)
$$


The survival function's value at the end of the jth year was represented as Equation (4):

$$
\operatorname{Pr}\left(T>a_{j}\right)=1-\bar{F}\left(a_{j}\right)=S\left(a_{j}\right)
$$

Finally, the probability of market exit within the relevant interval was calculated using Equation (5):

$$
\operatorname{Pr}\left(a_{j-1}<T \leq a_{j}\right)=F\left(a_{j}\right)-F\left(a_{j-1}\right)=S\left(a_{j-1}\right)-S\left(a_{j}\right)
$$

\subsubsection{Discrete Hazard Rate and Survival Function}

The hazard rate interval $h\left(a_{j}\right)$, also known as the discrete hazard rate, is the exit probability during the interval $\left(a_{j-1}, a_{j}\right)$, which was defined as Equation (6):

$$
h\left(a_{j}\right)=\operatorname{Pr}\left(a_{j-1}<T \leq a_{j} \mid \mathrm{T}>a_{j-1}\right)=(\ldots \ldots)=1-\frac{S\left(a_{j}\right)}{S\left(a_{j-1}\right)}
$$

Notably, the hazard time interval is a conditional probability, so it was expressed as Equation (7):

$$
0 \leq h\left(a_{j}\right) \leq 1
$$

In addition, time intervals are usually estimated as constants (e.g., years, months or weeks), which is why the hazard ratio $h\left(a_{j}\right)$ was transcribed as $h_{j}$, with $j=1,2,3 \ldots$ The survival probability until the end of interval $j$ is the product of a company's probability of not experiencing the exit event in each of the intervals up to and including the current one, as shown in Equation (8):

$$
S(j)=S_{j}=\left(1-h_{1}\right)\left(1-h_{2}\right) \ldots\left(1-h_{j-1}\right)\left(1-h_{j}\right)=\prod_{k=1}^{j}\left(1-h_{k}\right)
$$

$S(j)$ refers to a discrete-time survivor function written in terms of a hazard rate interval.

\subsubsection{Complementary Log-Log}

This research used a complementary log-log model, which basically estimates the parameters that describe the risk over a continuous period while taking into account the nature of the available survival time data for intervals [59] (p. 41). In the present study's model, the discrete-time interval hazard function $h\left(a_{j}, X\right)$ also called $h_{j}(X)$ was defined by Equation (9):

$$
h_{j}(X)=\frac{S\left(a_{j-1}, X\right)-S\left(a_{j}, X\right)}{S\left(a_{j-1}, X\right)}=1-\frac{S\left(a_{j}, X\right)}{S\left(a_{j-1}, X\right)}=1-\exp \left[\lambda\left(H_{j-1}-H_{j}\right)\right]
$$

This expression was transformed until either Equation (10):

$$
\log \left(-\log \left[1-h_{j}(X)\right]=\beta^{\prime} X+\gamma_{j}\right.
$$

or Equation (11) was reached:

$$
h\left(a_{j}, X\right)=1-\exp \left[-\exp \left(\beta^{\prime} X+\gamma_{j}\right)\right]
$$

in which $\gamma_{j}$ is the logarithm of the difference between the integrated baseline hazard $\theta(\mathrm{t})$ evaluated at the beginning and end of the interval $\left(a_{j-1}, a_{j}\right]$. The transformation $\log (-\log ()$.$) is known as the complementary \log -\log$ transformation. Thus, the proportional hazards model of discrete-time intervals is often referred to as a cloglog model. 


\section{Results}

The study analysed 29,655 observations corresponding to 2615 companies, among which 70 experienced failure and left the market. The hotel sample was $43.55 \%$ microcompanies, $44.57 \%$ small firms, $10.40 \%$ medium companies and $1.48 \%$ large firms, according to the European Commission's [60] classification system. Table 1 shows the sample's profile, and the Appendix A lists the correlations between variables. The mean, standard deviation, maximum and minimum values are included in this table.

Table 1. Sample profile ${ }^{\text {a }}$.

\begin{tabular}{|c|c|c|c|c|c|c|}
\hline Variable & & Mean & Standard Deviation & Minimum & Maximum & Observations \\
\hline Ln Sales & Overall & 7.77 & 1.31 & -4.12 & 13.33 & $\mathrm{n}=29,655$ \\
\hline \multirow{2}{*}{$(\ln ($ sales $€))$} & Between & & 1.27 & -0.69 & 13.14 & $\mathrm{n}=2589$ \\
\hline & Within & & 0.62 & -2.49 & 12.65 & t-bar $=11.45$ \\
\hline Cash Flows & Overall & 0.01 & 6.64 & -667.57 & 377.21 & $\mathrm{n}=29,657$ \\
\hline \multirow{2}{*}{ (thousands $€$ ) } & Between & & 3.81 & -131.75 & 43.18 & $\mathrm{n}=2590$ \\
\hline & Within & & 6.18 & -616.10 & 345.33 & $\mathrm{t}$-bar $=11.45$ \\
\hline \multirow{3}{*}{$\begin{array}{c}\text { Experience } \\
\text { (years) }\end{array}$} & Overall & 16.46 & 14.22 & -12 & 106 & $\mathrm{n}=29,657$ \\
\hline & Between & & 14.98 & -12 & 105 & $\mathrm{n}=2590$ \\
\hline & Within & & 0.80 & -19.08 & 57.92 & $\mathrm{t}$-bar $=11.4506$ \\
\hline Performance & Overall & 0.31 & 26.98 & 0 & $3,343,581$ & $\mathrm{n}=29,657$ \\
\hline \multirow[t]{2}{*}{ Rotation } & Between & & 8.66 & 0.00 & 358.39 & $\mathrm{n}=2590$ \\
\hline & Within & & 25.69 & -358.07 & $3,086,658$ & $\mathrm{t}$-bar $=11.45$ \\
\hline Working Cap. & Overall & 0.01 & 0.31 & -48.07 & 1 & $\mathrm{n}=29,657$ \\
\hline \multirow[t]{2}{*}{ /T.Assets } & Between & & 0.12 & -6.15 & 0.08 & $\mathrm{n}=2590$ \\
\hline & Within & & 0.29 & -41.91 & 6.18 & $\mathrm{t}$-bar $=11.45$ \\
\hline \multirow[t]{3}{*}{ Good Practic. } & Overall & 514.42 & $3,604,957$ & $-123,949$ & 191,641 & $\mathrm{n}=29,657$ \\
\hline & Between & & $2,328,923$ & $-14,457.57$ & $81,389.35$ & $\mathrm{n}=2590$ \\
\hline & Within & & 2690.7 & $-115,854.8$ & $171,050.3$ & $\mathrm{t}$-bar $=11.45$ \\
\hline
\end{tabular}

a Along with these variables, a dichotomous variable was incorporated that indicates the CEO's gender with a value of one if it is female and zero value in the case of the male gender. In addition, the endogenous variable was the status of the company with a value of 1 if the company had closed and zero in the other cases.

The results obtained by applying the complementary log-log model are shown in Table 2.

Table 2. Complementary log-log regression.

\begin{tabular}{|c|c|c|c|}
\hline Variable & Coefficient & Hazard Rate & $p$-Value \\
\hline Ln_Sales & -0.290 & 0.748 & $0.000^{* * *}$ \\
\hline Cash Flows & 0.001 & 1.001 & 0.388 \\
\hline Experience & -0.033 & 0.967 & $0.043^{* *}$ \\
\hline CEO Gender & -1.475 & 0.229 & $0.003^{* * *}$ \\
\hline Performance Rotation & -0.001 & 0.999 & $0.021^{* *}$ \\
\hline Ratio Working Capital/Total Assets & 1.436 & 1731771 & $0.030 * *$ \\
\hline $\begin{array}{c}\text { Good Practices/Earnings before } \\
\text { Interest and Taxes }\end{array}$ & 0.00000782 & 1.000 & 0.854 \\
\hline _ Cons & -3444529 & 0.032 & $0.000 * * *$ \\
\hline$/ \operatorname{lnsig} 2 \mathrm{u}$ & -9.614 & & \\
\hline sigma_u & 0.008 & & \\
\hline rho & 0.000041 & & \\
\hline
\end{tabular}


In Table 2, the variable logarithm of sales, experience (i.e., years in the hotel industry before the study period), executive director's gender and ratio of working capital to total assets are statistically significant. This result means that sales and experience have a positive relationship with hotel survival and that hotels run by women have a better (i.e., negative $\beta$ coefficients) survival rate. However, the working capital to total assets ratio has a negative influence on survival. That is, an excess of working capital over total assets (i.e., positive $\beta$ coefficient) can be indicative of inefficiency and can harm the company's chance of survival [61].

The results shown in Table 2 above also include the hazard function (i.e., hazard ratio). Regarding the logarithm of sales, the complementary log-log regression model produced a hazard ratio of 0.7481388 . This value can be interpreted as follows. When a company's logarithm of sales is reduced, that hotel has a risk rate or instantaneous death rate of $25.18 \%$. In terms of the ratio of working capital to total assets, the results reveal a positive relationship with the risk of market exit. The intervals do not include the hazard ratio null value of 1 , so each variable's effect is significant (i.e., $|p|<0.05$ ).

Regarding the interpretation of coefficients and hazard rates, companies that have a woman as CEO have a longer duration, which means that they end up closing later than companies managed by men. If the hazard rate is analysed, it is interpreted that companies that have a woman as CEO, the risk of company closure is $0.229-1=77.1 \%$ lower. In other words, businesses run by women are more likely to survive than those run by men.

\section{Discussion}

Table 3 presents a summary of the hypothesis validation. The hypotheses that are accepted with the expected sign are that the age or experience of the company, the size, the performance rotation ratio and the hotel CEOs' gender (female) are positively related to survival (or negatively to the risk of closure of the company). However, there are two hypotheses that cannot be validated: The relationship of cash flow and good management practices with survival (or with the risk at the closing of the company). A hypothesis (H5) has also been validated but with the opposite sign as expected: Working capital/total assets ratio is negatively related to survival.

Table 3. Summary of hypothesis validation.

\begin{tabular}{lcc}
\hline Hypothesis & Accepted/Rejected & Expected Sign \\
\hline H1: Companies' age is related to survival & Accepted (+) & Yes \\
H2: Companies' size is related to survival & Accepted (+) & Yes \\
H3: Companies' cash flows are related to survival & Rejected & No \\
H4: Performance rotation ratio is related to survival & Accepted $(+)$ & Yes \\
H5: Working capital / Total Asssets ratio is related to survival & Accepted (-) & No \\
H6: Good management practices are related to survival & Rejected & No \\
H7: Hotel CEOs' gender (female) are related to survival & Accepted (+) & Yes \\
\hline
\end{tabular}

'Accepted $(+)$ ' means that it is accepted that this variable is positively related to survival. 'Accepted (-)' means that it is accepted that this variable is negatively related to survival. 'Expected Sign' informs whether the positive or negative sign of the relationship with survival was as expected.

The findings confirm previous research results reported by other authors such as [62]. According to the cited authors, the risk of insolvency in new companies is reduced by $77.1 \%$ in firms with at least one woman on the board of directors. This finding is consistent with various studies that have found that female-led hotel businesses have better survival rates.

The quite significant effect of this survival factor can be explained by other disciplines such as psychology [63], as well as financial research. The latter has confirmed that companies run by women are characterised by a reduction in risk taking [53]. This risk reduction also implies lower leverage. Various studies have also confirmed that women have a more conservative attitude towards credit and cash flow management [64-66] and lower delinquency rates [67]. Women's investment decisions are less risky [68], and female managers can generate better company financing. Overall, researchers have found that 
firms with female CEOs tend to reduce their level of risk in the capital market and their share volatility [69], which ensures greater access to company financing. Analysts and investors obtain better information about firms' results when their board of directors is more diverse [70], thereby improving the companies' image among these two groups of stakeholders.

In addition, the positive relationship between hotel firms' working capital to total assets ratio and risk of death indicates that an excess of working capital versus total assets hurts these establishments. Companies with excessive working capital run different risks [61] including that their capital does not generate any return for the hotel and that the danger exists of unnecessary inventory accumulation, faulty credit policies and loose collection periods. Bad debts negatively affect profits. Too much working capital also makes firms' management and administration practices more inefficient and expensive [61].

Any interpretation of the present results, however, needs to bear in mind that previous studies using this ratio focused on listed companies. In the present research, most companies in the sample were micro and small businesses with fewer opportunities to access funding and to benefit from financial leverage's effects.

\section{Conclusions}

\subsection{Theoretical Implications}

This research is the first to relate gender diversity and business survival in the hospitality sector. The findings include which factors function as mediators between gender diversity and survival, as determined by qualitative analysis. Other aspects related to this topic need to be analysed more deeply, such as corporate governance and the relationships between CEO gender, sustainable strategies and business survival. The main theoretical implication is the successful use of survival models to process discrete-time data on when survival happens in a continuous period, although spell durations were observed only in intervals (i.e., grouped data).

\subsection{Practical Implications}

Hotel companies should consider choosing women executive directors to help these firms survive the crisis triggered by the COVID-19 pandemic. Hotels can also increase their board of director's critical mass to at least three female members in order to achieve more rigorous monitoring of company activities and promote efficiency, as suggested by Schwartz-Ziv [71].

The present results have other important management implications as the findings include that being a sufficiently large size is important for survival. Hotel managers must take into account the minimum size needed to ensure efficient operations from the start since, below that size, the risk of closure remains a constant. Any moves made towards mergers or acquisitions will thus improve companies' chance of survival.

Caution must be exercised in applying these findings, and the limitations of bankruptcy prediction methods need to be kept in mind. Nonetheless, implementing methods that provide an early warning of vulnerabilities could prevent many bankruptcies as survival analysis-based strategies could help hotels restructure in time to avoid bankruptcy. In addition, the experience gained by hotels that have been open for years could be essential to dealing with problems that put these companies' survival at risk.

\subsection{Limitations and Future Lines of Research}

Regarding limitations, other aspects that could influence hotel businesses' bankruptcy were not considered by the present study, such as factors related to corporate governance. Recent empirical studies' results indicate that companies' failure is associated with more concentrated ownership, weak shareholder rights, poor financial transparency and a less effective board of directors [72]. Female CEOs further promote more active boards of directors when the boards reach the critical mass of at least three female members, and, in turn, gender-balanced boards are more likely to replace low-performing CEOs [71]. 
Research on these factors could strengthen the evidence indicating that women hotel CEOs foster better management practices and increase their company's chances of survival, thus confirming the present study's results.

Another limitation is that this research did not consider relationships between hotel firms, which other authors have highlighted [19]. Including this variable could open a new field of study. Possible future lines of investigation to overcome the current research's limitations include analyses of hotel corporate governance, in addition to company survival and executive directors' gender.

Further research on this topic could follow up on the current study and extend it to include other sets of variables, such as boards of directors' structure, or differentiate between family and non-family businesses. Interesting results might also be obtained by conducting parallel research that distinguishes between individual and group hotels. Finally, similar analyses could be carried out in other geographical settings.

Author Contributions: Conceptualization, M.E.-N. and G.G.; methodology, M.E.-N. and G.G.; software, M.E.-N. and G.G.; validation, M.E.-N. and G.G.; formal analysis, M.E.-N. and G.G.; investigation, M.E.-N. and G.G.; resources, M.E.-N. and G.G.; data curation, M.E.-N. and G.G.; writingoriginal draft preparation, M.E.-N. and G.G.; writing—review and editing, M.E.-N. and G.G.; supervision, M.E.-N. and G.G.; project administration, M.E.-N. and G.G. All authors have read and agreed to the published version of the manuscript.

Funding: This research was funded for open access charge by University of Malaga/CBUA.

Institutional Review Board Statement: Not applicable.

Informed Consent Statement: Not applicable.

Data Availability Statement: The data presented in this study are available on request from the corresponding author.

Conflicts of Interest: The authors declare no conflict of interest.

\section{Appendix A}

Table A1. Variable correlation matrix.

\begin{tabular}{lcccccc}
\hline & $\mathbf{1}$ & $\mathbf{2}$ & $\mathbf{3}$ & $\mathbf{4}$ & $\mathbf{5}$ & $\mathbf{6}$ \\
\hline 1. Ln Sales & 1.000 & & & & & \\
2. Cash Flows & 0.011 & 1.000 & & & & \\
3. Experience & 0.118 & -0.001 & 1.000 & & & \\
4. Performance Rotation & -0.009 & 0.000 & -0.005 & -0.004 & & \\
5. Working Capital Ratio & 0.044 & -0.021 & -0.021 & 0.004 & 1.000 & \\
6. Good Practices & 0.226 & 0.002 & 0.039 & 0.013 & 0.000 & 1.000 \\
\hline
\end{tabular}

\section{References}

1. UNWTO World Tourism Organization. International Tourism and Covid-19 UNWTO. Available online: https:/ /www.unwto. org/international-tourism-and-covid-19 (accessed on 19 April 2021).

2. Richard, B. Hotel chains: Survival strategies for a dynamic future. J. Tour. Future 2017, 3, 56-65. [CrossRef]

3. Michael Hall, C. Crisis events in tourism: Subjects of crisis in tourism. Curr. Issues Tour. 2010, 13, 401-417. [CrossRef]

4. Gössling, S.; Scott, D.; Hall, C.M. Pandemics, tourism and global change: A rapid assessment of COVID-19. J. Sustain. Tour. 2021, 29, 1-20. [CrossRef]

5. Hall, C.M. Degrowing tourism: Décroissance, sustainable consumption and steady-state tourism. Anatolia $2009,20,46-61$. [CrossRef]

6. Mair, J.; Ritchie, B.W.; Walters, G. Towards a research agenda for post-disaster and post-crisis recovery strategies for tourist destinations: A narrative review. Curr. Issues Tour. 2016, 19, 1-26. [CrossRef]

7. Ramón-Dangla, R. La huella de la crisis y la estrategia de supervivencia en la industria hotelera Española: Una aproximación a través de los estados financieros. Tour. Manag. Stud. 2016, 12, 117-126. [CrossRef]

8. Zenker, S.; Kock, F. The coronavirus pandemic-A critical discussion of a tourism research agenda. Tour. Manag. 2020, 81, 104164. [CrossRef] [PubMed] 
9. Ravi Kumar, P.; Ravi, V. Bankruptcy prediction in banks and firms via statistical and intelligent techniques-A review. Eur. J. Oper. Res. 2007, 180, 1-28. [CrossRef]

10. Veganzones, D.; Severin, E. Corporate failure prediction models in the twenty-first century: A review. Eur. Bus. Rev. 2020, 33, 204-226. [CrossRef]

11. Campbell, K.; Mínguez-Vera, A. Gender diversity in the boardroom and firm financial performance. J. Bus. Ethics 2008, 83, 435-451. [CrossRef]

12. Joecks, J.; Pull, K.; Vetter, K. Gender Diversity in the Boardroom and Firm Performance: What Exactly Constitutes a "Critical Mass"? J. Bus. Ethics 2013, 118, 61-72. [CrossRef]

13. Mooney, S.; Ryan, I. A woman's place in hotel management: Upstairs or downstairs? Gend. Manag. 2009, 24, 195-210. [CrossRef]

14. Kliestik, T.; Misankova, M.; Valaskova, K.; Svabova, L. Bankruptcy Prevention: New Effort to Reflect on Legal and Social Changes. Sci. Eng. Ethics 2018, 24, 791-803. [CrossRef]

15. Ohlson, J.A. Financial Ratios and the Probabilistic Prediction of Bankruptcy. J. Account. Res. 1980, 18, 109. [CrossRef]

16. Amankwah-Amoah, J. A unified framework for incorporating decision making into explanations of business failure. Ind. Manag. Data Syst. 2015, 115, 1341-1357. [CrossRef]

17. Udenio, M.; Fransoo, J.C.; Peels, R. Destocking, the bullwhip effect, and the credit crisis: Empirical modeling of supply chain dynamics. Int. J. Prod. Econ. 2015, 160, 34-46. [CrossRef]

18. Chiu, W.C.; Peña, J.I.; Wang, C.W. Do structural constraints of the industry matter for corporate failure prediction? Invest. Anal. J. 2013, 78, 65-81. [CrossRef]

19. Tobbacka, E.; Moeyersoms, J.; Stankova, M.; Martens, D. Bankruptcy prediction for SME's using relational data. Decis. Support Syst. 2017, 102, 69-81. [CrossRef]

20. Fitzpatrick, P.J. A Comparison of the Ratios of Successful Industrial Enterprises with Those of Failed Companies; The Accountants Publishing Company: Washington, DC, USA, 1932.

21. Beaver, W.H. Financial Ratios as Predictors of Failure. J. Account. Res. 1966, 4, 71-111. [CrossRef]

22. Altman, E.I. Financial Ratios, Discriminant Analysis and the Prediction of Corporate Bankruptcy. J. Financ. 1968, 23, 589-609. [CrossRef]

23. García-Gallego, A.; Mures-Quintana, M.J. Principal components and canonical correlation analyses as complementary tools. Application to the processing of financial information. Econ. Comput. Econ. Cybern. Stud. Res. 2016, 50, $249-266$.

24. Li, Z.; Crook, J.; Andreeva, G. Dynamic prediction of financial distress using Malmquist DEA. Expert Syst. Appl. 2017, 80, 94-106. [CrossRef]

25. Olson, D.L.; Delen, D.; Meng, Y. Comparative analysis of data mining methods for bankruptcy prediction. Decis. Support Syst. 2012, 52, 464-473. [CrossRef]

26. Kim, S.; Mun, B.M.; Bae, S.J. Data depth based support vector machines for predicting corporate bankruptcy. Appl. Intell. 2018, 48, 791-804. [CrossRef]

27. Wennberg, K.; Wiklund, J.; DeTienne, D.R.; Cardon, M.S. Reconceptualizing Entrepreneurial Exit: Different Exit Routes and Their Drivers. J. Bus. Ventur. 2010, 25, 361-375. [CrossRef]

28. Delmar, F.; McKelvie, A.; Wennberg, K. Untangling the Relationships Mong Growth, Profitability and Survival in New Firms. Technovation 2013, 33, 276-291. [CrossRef]

29. Renski, H. External economies of localization, urbanization and industrial diversity and new firm survival. Pap. Reg. Sci. 2010, 90. [CrossRef]

30. Rauch, A.; Rijsdijk, S.A. The Effects of General and Specific Human Capital on Long-Term Growth and Failure of Newly Founded Businesses. Entrep. Theory Pract. 2013, 37, 923-941. [CrossRef]

31. Kato, M.; Honjo, Y. Entrepreneurial human capital and the survival of new firms in high- and low-tech sectors. J. Evol. Econ. 2015, 25, 925-957. [CrossRef]

32. Everett, J.; Watson, J. Small Business Failure and External Risk Factors. Small Bus. Econ. 1998, 11, 371-390. [CrossRef]

33. Watson, J. Networking: Gender differences and the association with firm performance. Int. Small Bus. J. 2012, 30, 536-558. [CrossRef]

34. Goto, H.; Takayasu, H.; Takayasu, M. Estimating risk propagation between interacting firms on inter-firm complex network. PLoS ONE 2017, 12, e185712. [CrossRef] [PubMed]

35. Li, S.; Sui, X. Contagion risk in endogenous financial networks. Chaos Solitons Fractals 2016, 91, 591-597. [CrossRef]

36. Brüderl, J.; Preisendörfer, P.; Ziegler, R. Survival Chances of Newly Founded Business Organizations. Am. Sociol. Rev. 2013, 57, 227-242. [CrossRef]

37. Chen, X.; Zou, H.; Wang, D.T. How do new ventures grow? Firm capabilities, growth strategies and performance. Int. J. Res. Mark. 2009, 26, 294-303. [CrossRef]

38. Valls Martínez, M.d.C.; Cruz Rambaud, S. Women on corporate boards and firm's financial performance. Womens Stud. Int. Forum 2019, 76, 102251. [CrossRef]

39. Reguera-Alvarado, N.; de Fuentes, P.; Laffarga, J. Does Board Gender Diversity Influence Financial Performance? Evidence from Spain. J. Bus. Ethics 2017, 141, 337-350. [CrossRef]

40. Kanter, R.M. Men and Women of the Corporation Revisited: Interview with Rosabeth Moss Kanter. Hum. Resour. Manag. 1987, 26, 257-263. [CrossRef] 
41. Carter, D.A.; D'Souza, F.; Simkins, B.J.; Simpson, W.G. The gender and ethnic diversity of US boards and board committees and firm financial performance. Corp. Gov. An Int. Rev. 2010, 18, 396-414. [CrossRef]

42. Lin, S.C.; Kim, Y.R. Diversification strategies and failure rates in the Texas lodging industry: Franchised versus company-operated hotels. Int. J. Hosp. Manag. 2020, 88, 102525. [CrossRef]

43. Türkcan, K.; Erkuş-Öztürk, H. The impact of economic and political crises on the survival of tourism-related firms: Evidence from Antalya. Tour. Econ. 2019. [CrossRef]

44. Vivel-Búa, M.; Lado-Sestayo, R.; Otero-González, L. Influence of firm characteristics and the environment on hotel survival across MSMES segments during the 2007-2015 period. Tour. Manag. 2019, 75, 477-490. [CrossRef]

45. Hamilton, E.A. An exploration of the relationship between loss of legitimacy and the sudden death of organizations. Gr. Organ. Manag. 2006, 31, 327-358. [CrossRef]

46. Heracleous, L.; Werres, K. On the Road to Disaster: Strategic Misalignments and Corporate Failure. Long Range Plan. 2016, 49, 491-506. [CrossRef]

47. Bruderl, J.; Schussler, R. Organizational Mortality: The Liabilities of Newness and Adolescence. Adm. Sci. Q. 1990, 35, 530-547. [CrossRef]

48. Li, H.; Sun, J. Forecasting business failure: The use of nearest-neighbour support vectors and correcting imbalanced samplesEvidence from the Chinese hotel industry. Tour. Manag. 2012, 33, 622-634. [CrossRef]

49. Gemar, G.; Soler, I.P.; Guzman-Parra, V.F. Predicting bankruptcy in resort hotels: A survival analysis. Int. J. Contemp. Hosp. Manag. 2019, 31, 1546-1566. [CrossRef]

50. Winter, M.; Danes, S.M.; Koh, S.K.; Fredericks, K.; Paul, J.J. Tracking family businesses and their owners over time: Panel attrition, manager departure and business demise. J. Bus. Ventur. 2004, 19, 535-559. [CrossRef]

51. Watson, J.; Robinson, S. Adjusting for risk in comparing the performances of male- and female-controlled SMEs. J. Bus. Ventur. 2003, 18, 773-788. [CrossRef]

52. Bennouri, M.; Chtioui, T.; Nagati, H.; Nekhili, M. Female board directorship and firm performance: What really matters? J. Bank. Financ. 2018, 88, 267-291. [CrossRef]

53. Khan, W.A.; Vieito, J.P. Ceo gender and firm performance. J. Econ. Bus. 2013, 67, 55-66. [CrossRef]

54. Vieito, J.P.T. Gender, top management compensation gap, and company performance: Tournament versus behavioral theory. Corp. Gov. An Int. Rev. 2012, 20, 46-63. [CrossRef]

55. Faccio, M.; Marchica, M.T.; Mura, R. CEO gender, corporate risk-taking, and the efficiency of capital allocation. J. Corp. Financ. 2016, 39, 193-209. [CrossRef]

56. Yeh, C.M.; Trejos, B. The influence of governance on tourism firm performance. Curr. Issues Tour. 2015, 18, 299-314. [CrossRef]

57. Stein, G.; Plaza, S.; Susaeta, L. Estudio sobre la rotación del CEO en las grandes sociedades cotizadas españolas (2001-2010). IESE Bus. Sch. Univ. Navarra 2011, 3.

58. Gémar, G.; Moniche, L.; Morales, A.J. Survival analysis of the Spanish hotel industry. Tour. Manag. 2016, 54, 428-438. [CrossRef]

59. Jenkins, S.P. Survival Analysis; 2005; Available online: https://www.iser.essex.ac.uk/files/teaching/stephenj/ec968/pdfs/ec968 lnotesv6.pdf (accessed on 19 April 2021).

60. Commission E. European Commission. Commission recommendation of 6 May 2003 on the definition of micro, small and medium-sized enterprises. Off. J. Eur. Communities 2003, L124, 36-41.

61. Reddy, P.N.; Appannaiah, H.R.; Sathyaprasad, B.G. Business Management-II: Marketing and Finance; Global Media: Mumbai, India, 2009; ISBN 9789350431603.

62. Wilson, N.; Altanlar, A. Director Characteristics, Gender Balance and Insolvency Risk: An Empirical Study. Unpublished 2011. [CrossRef]

63. Lahtinen, K.D. Motivating gender use in financial research: A survey of recent literature. Rev. Behav. Financ. 2019, 12, 242-258. [CrossRef]

64. Fang, L.H.; Huang, S. Gender and connections among wall street analysts. Rev. Financ. Stud. 2017, 30, 3305-3335. [CrossRef]

65. Moro, A.; Wisniewski, T.P.; Mantovani, G.M. Does a manager's gender matter when accessing credit? Evidence from European data. J. Bank. Financ. 2017, 80, 119-134. [CrossRef]

66. Wilson, N.; Wright, M.; Altanlar, A. The survival of newly-incorporated companies and founding director characteristics. Int. Small Bus. J. Res. Entrep. 2014, 32, 733-758. [CrossRef]

67. Beck, T.; Behr, P.; Guettler, A. Gender and banking: Are women better loan officers? Rev. Financ. 2013, 17, 1279-1321. [CrossRef]

68. Felton, J.; Gibson, B.; Sanbonmatsu, D.M. Preference for Risk in Investing as a Function of Trait Optimism and Gender. J. Behav. Financ. 2003, 4, 33-40. [CrossRef]

69. Martin, A.; Nishikawa, T.; Williams, M. CEO gender: Effects on valuation and risk. Q. J. Financ. Account. 2009, $48,23-41$.

70. Gul, F.A.; Hutchinson, M.; Lai, K.M.Y. Gender-Diverse Boards and Properties of Analyst Earnings Forecasts. Account. Horizons 2013, 27, 511-538. [CrossRef]

71. Schwartz-Ziv, M. Gender and Board Activeness: The Role of a Critical Mass. J. Financ. Quant. Anal. 2017, 52, 751-780. [CrossRef]

72. Fernando, J.M.R.; Li, L.; Hou, Y. (Greg) Corporate governance and default prediction: A reality test. Appl. Econ. 2019, 51, 2669-2686. [CrossRef] 